\title{
Bankers' perception on the Implementation of sustainable finance in Indonesia
}

\author{
Alin Halimatussadiah ${ }^{1, *}$, Aria Farahmita ${ }^{2}$, Zakir Machmud ${ }^{1}$, Atiqah Amanda Siregar ${ }^{1}$, \\ Sulistiadi Dono Iskandar ${ }^{1}$, and Nia Kurnia Sholihah ${ }^{1}$ \\ ${ }^{1}$ Department of Economics, Faculty of Economics and Business, Universitas Indonesia, Kampus UI, \\ Depok, 16424, Indonesia \\ ${ }^{2}$ Department of Accounting, Faculty of Economics and Business, Universitas Indonesia, Kampus UI, \\ Depok, 16424, Indonesia
}

\begin{abstract}
Financial institution has critical role in driving sustainability. As the primary target of Sustainable Finance Roadmap, Financial Service Authority (OJK) is expecting this institution to incorporate the social and environment aspects into their business process and increase their portfolio in financing green projects, so the implementation will not only affect the banking sector, but also the real sector. However, this concept is relatively new in Indonesia. Therefore, improving the understanding, knowledge, and competence of banking officers, are essential to support the implementation of sustainable finance. This study aims to see the perspective of those bankers about the sustainable finance, particularly on the implementation of Environment and Social Risk Assessment (ESRA) and green portfolio. From what is found, this study showed a different result between local and foreign banks in Indonesia.
\end{abstract}

\section{Introduction}

In the latest draft of the Global Sustainable Development Report 2019, a group of scientists asserts that the world needs a massive economic transition more than ever to tackle the issue of climate change [1]. The rapid environmental degradation in recent decades does not only affect the environment itself, but also rising issues about inequality, unemployment, also slowing the economic growth. Therefore, government along with other relevant stakeholders need to work together to achieve better and more sustainable economic conditions.

As a financial intermediaries that drives the country's economy, financial sectors are expected to promote more sustainable business process in financial industry. The impact of a more sustainable business in financial industry will go beyond the industry itself. The benefits of practicing sustainable finance are not limited to the environmental benefits, but also including the greater banking operational efficiencies and lowering risk along with the cost reduction [2]. Furthermore, this is expected to bring not only the financial institutions, but also any other relevant stakeholders, such as the real sectors and regulators, to work together to achieve more sustainable economy in general. In some case, failing in

*Corresponding author: alin.halimah@gmail.com 
encountering the environmental issues would lead to legal problem. United States has enacted the Comprehensive Environmental Response, Compensation and Liability Act (CERCLA). When the court decides that bank is liable to the environmental damage caused by the firms, this will incentivize bank to assess the environmental and social risks. The firms as borrower will also be obliged to commit to take preventive action and manage business in more sustainable way [3]. Several mainstream challenges faced by banks in implemeting the sustainable finance are including the lack of capacity, both institutional and human resources, knowledge gap, and even the availability of regulatory frameworks.

In 2014, the Financial Services Authority (OJK) launched the 2014-2024 Roadmap of Sustainable Finance in Indonesia. This roadmap has two main objectives mentioned that financial institutions need to incorporate the social and environmental risks into their business processes and increase their green portfolio. In supporting the implementation of sustainable finance, the adequate capacity of financial institutions, in terms of institutions and human resources, is needed so the optimal implementation of sustainable finance can be realized. The role of financial institutions, especially banking industry, are very critical in promoting sustainable development in general.

Currently, the concept of sustainable finance is still in the early stage of its development in Indonesia, so the lack of understanding, knowledge, and competence of human resources need to be improved to support the implementation of sustainable finance. For instance, the credit analysts may have difficulties in assessing the environment and social risk in loan approval of one particular renewable energy project. Hence, this study aims to see the perspective of those bankers about the sustainable finance, particularly on the implementation of Environment and Social Risk Assessment (ESRA) and green portfolio.

\section{Methods}

This empirical study focuses on using qualitative approach, considering the level of sustainable finance implementation in Indonesia is still at the early stage. However, the quantitative data will also be gathered to support the qualitative result. The qualitative data was collected using several methods, including in-depth interview and survey. These methods are used to capture the banks' current conditions, particularly about the perception, knowledge and skill of banking officers related to the implementation of sustainable finance in their own institutions. The selected samples are 84 respondents including the middle to low banking officers whose experience at least one year in banking industries. These selected respondents are representatives of the government bank, private bank, both local and foreign banks, and sharia bank, located in Jakarta, Indonesia. Moreover, the distribution of selected samples is covering the three of BUKU classifications, namely as BUKU 4, 3, and 2. According to the regulations of Central Bank of Indonesia (PBI), every bank belongs to one category known as BUKU, stands for Bank Umum Kegiatan Usaha, which divided based on the total of bank's core capital. Bank is categorized as BUKU 4 if it has at least IDR 30 trillion of core capital.

There are two main things that determined the process of sample selection; size of the bank and its exposure towards the assessment of environment and social risk. Each bank will have different weights which classified based on its size. Banks of BUKU 4 will have greater weight compare to other banks, considering the characteristic of Indonesian banking industry is still dominated by banks from this classification which account for more than $50 \%$ of total assets of local banking even though there are only four banks belong to this category. The local bank refers to the private bank, government bank and sharia bank.

Another factor taken into consideration is the level of exposure of each bank towards the assessment of environment and social risk which commonly known as ESRA-the Environment and Social Risk Assessment. Each bank experiences various degrees on the 
exposure to ESRA, therefore the samples cover both banks that have been or have not been exposed to ESRA to ensure the representation of each group. However, the banks with a high degree of ESRA exposure are prioritized to be respondent in this study.

\section{Results and discussion}

\subsection{Demographic information}

This study was specifically questioned the banking officers who have participate in the training of sustainable finance held by Financial Service Authority (OJK) in collaboration with USAID-ICED. Prior to their participation in this survey, only 2 out of 84 respondents who did not participate in the training. Therefore, $98 \%$ of the respondents have basic understanding about concept of sustainable finance.

Table 1. Profile of respondents.

\begin{tabular}{|c|c|c|}
\hline Variable & Categories & Percentage \\
\hline \multirow{4}{*}{ Age (in } & $<26$ & $0 \%$ \\
years) & $26-30$ & $19.1 \%$ \\
& $31-35$ & $23.8 \%$ \\
& $36-40$ & $19.1 \%$ \\
& $41-50$ & $32.1 \%$ \\
& $>50$ & $6 \%$ \\
\hline \multirow{3}{*}{ Education } & High school or equivalent & $0 \%$ \\
& Diploma or equivalent & $1.2 \%$ \\
& Magister (S2) or equivalent & $54.8 \%$ \\
& Doctoral (S3) & $44.1 \%$ \\
\hline \multirow{2}{*}{ Gender } & Male & $0 \%$ \\
\hline & Female & $67.9 \%$ \\
\hline
\end{tabular}

There are two things worth noting from the survey result. First, the number of respondents from local private bank are lower than the targeted number. This is due to the majority of banks in BUKU 4 classification is occupied by the government bank. Meanwhile at the level of bank BUKU 3, several banks that were once local private banks have now changed their status to foreign banks. This makes proportion of local private banks, which previously considered as significant in terms of size or ESRA exposure, now are relatively small so they did not meet the number of targeted respondents.

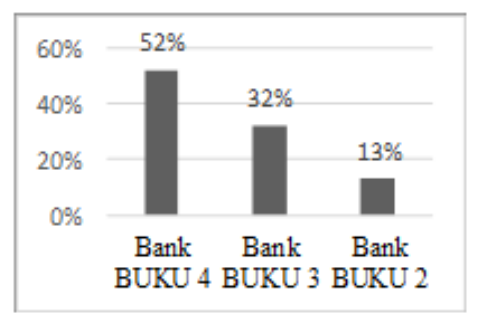

Fig. 1. Proportion of respondents based on size of bank.

And the second thing is the low participation of respondents from Islamic banks in this survey activities. This is due to the technical difficulties experienced, including the difficulties in contacting the targeted respondents from Islamic banks which caused by 
various things, such as the respondent is being out of town, has been transferred to other branches or has resigned from the bank. Nevertheless, the number of respondents has represented each types of bank which portraying the current condition of sustainable finance in Indonesian banking industry.

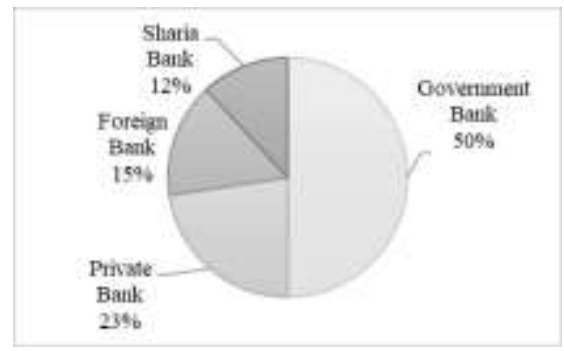

Fig. 2. Proportion of respondents based on types of bank.

\subsection{Bankers' knowledge, understanding, and perception about the implementation of sustainable finance}

According to the survey result, most of banks are agree that more effort is needed to enhance bankers' capacity and incorporate ESRA into process of credit analysis. Although the banks are also most likely will be incorporating ESRA in the future, they still experienced many difficulties in implementing ESRA. Therefore, they agree that adequate capacity building is needed which may also support the increasing of banks' green portfolio. Even at this current state, the respondents believe that market will have positive response on banks' issuance of green financial products.

Most of local banks have known the Roadmap of Sustainable Finance published by OJK. However, their knowledge related to the concept of sustainable finance is still limited. In fact, some of medium-scaled local banks (Bank BUKU 3 and 2) still have very limited knowledge about sustainable finance. Almost all of local banks also have limited understanding on any international best practice and international standards of sustainable finance. Only a few bankers understand and have knowledge particularly related to the Environment and Social Risk Assessment (ESRA).

In contrast to the local banks, the respondents from foreign banks has better and more comprehensive understanding about the principles of sustainable finance, especially related to the environmental and social aspect. They even stated that they are inclined to adopt the principles of sustainable finance as the application of these principles are increasingly embedded to the banking best practices in the future. Nonetheless, $99 \%$ of survey respondents stated that they still needed additional capacity building to improve their skills in assessing social and environmental risks, also assessing the environmental documents.

\subsection{The implementation of sustainable finance}

Due to the limited knowledge and understanding of the majority of local banks relative to other banks, the implementation of sustainable finance is also still partial, sporadic, ad hoc, undocumented, and unpublished. It is quite surprising as most respondents claim that ESRA has been incorporated in to the process of credit analysis.

Most of these banks, especially local banks, are waiting for more detailed regulations issued by OJK as reference to the implementation of sustainable finance. On the other hand, the foreign banks most likely have integrated the concept of sustainable finance into company values and policies. Everything is well-documented and published as continuous reports. But in the stage of implementation, the results are still fragmented. For instance, 
several exceptions are still found in the process of credit assessment. This may occur due to the different conditions, like regulatory issues, between Indonesia and the country of origin.

In addition, the target proportion of green credit is not explicitly specified. In foreign banks, the degree of implementation of sustainable finance generally depends on the global policy of the bank. However, not every foreign bank implemented sustainable finance or adopted ESRA although most of them did. In general, banks that are directly branches of the holding company have adopted the global policy entirely, compared to the banks that are subsidiaries of foreign banks.

Table 2. Perception on the implementation of sustainable finance.

\begin{tabular}{|l|c|c|c|c|}
\hline \multicolumn{1}{|c|}{ Perception } & $\begin{array}{c}\text { Strongly } \\
\text { disagree } \\
\text { (\%) }\end{array}$ & $\begin{array}{c}\text { Disagree } \\
\mathbf{( \% )}\end{array}$ & $\begin{array}{c}\text { Agree } \\
\mathbf{( \% )}\end{array}$ & $\begin{array}{c}\text { Strongly } \\
\text { agree } \\
\mathbf{( \% )}\end{array}$ \\
\hline $\begin{array}{l}\text { More effort is needed to enhance bankers' } \\
\text { capacity }\end{array}$ & & 35.7 & 52.38 & 44.05 \\
\hline More effort is needed to increase green portfolio & & 8.33 & 60.71 & 30.95 \\
\hline More effort is needed in incorporating ESRA & & 2.38 & 59.52 & 38.10 \\
\hline Possibility in incorporating ESRA & & 1.19 & 75 & 23.81 \\
\hline Possibility of enacting green portfolio policy & & 5.95 & 72.62 & 21.43 \\
\hline $\begin{array}{l}\text { Market acceptance on sustainable products (green } \\
\text { bonds, green lending, etc) }\end{array}$ & & 10.71 & 70.24 & 19.05 \\
\hline $\begin{array}{l}\text { Experience many difficulties in implementing } \\
\text { ESRA in business process }\end{array}$ & 4.76 & 65.48 & 23.81 & 5.95 \\
\hline Adequate capacity building for bankers & 1.19 & 42.86 & 53.57 & 2.38 \\
\hline $\begin{array}{l}\text { Bank needs to pay attention on triple bottom line } \\
\text { (people, profit, planet) }\end{array}$ & & & 52.38 & 47.62 \\
\hline Bank has critical role in reducing GHG emissions & 1.19 & 13.10 & 67.86 & 17.86 \\
\hline $\begin{array}{l}\text { Bank has critical role in reducing negative impact } \\
\text { of business activity }\end{array}$ & 1.19 & 5.95 & 71.43 & 21.43 \\
\hline
\end{tabular}

Some concerns of banks related to the implementation of sustainable finance regulations are covering; (a) the clarity of relevant rules and regulations; (b) the implementation of this principle should be adjustable to the different characteristics of banks, which also means not one-size-fits-all policy; (c) the availability of incentive/disincentive mechanism; and (d) the existence of staging in the process of implementation. Some respondents also expressed that the implementation of sustainable finance requires support, coordination and law enforcement from other relevant agencies, such as Ministry of Environment and Forestry (KLHK) and regulators in the real sector, including Ministry of Energy and Mineral Resources (ESDM), Ministry of Agriculture, Ministry of Industry, and so forth.

\section{Conclusions}

Financial intermediaries or banking industry have key roles in supporting the achievement of sustainable development goals. Moreover, this industry may have profound effect in promoting more sustainable finance, both for the institution itself and the real sectors financed by banking industry, which can also reduce the overall risks.

This study reveals that banking officers have good knowledge and understanding about the importance of incorporating ESRA into their credit selection process. Furthermore, the 
respondents are also sure that most likely their institution will integrate ESRA and increase the green portfolios in the future. However, the bankers are also aware about their limited knowledge of technical details on how to assess these risks. The current implementation of sustainable finance in banking industry is also still limited. In this early stage, OJK as regulator still has main roles to support the development of sustainable banking industry in Indonesia. Furthermore, it will be better if among ministries are also started to discuss about the more comprehensive approach to promote sustainable finance. For instance, the discussion about incentives or disincentives mechanism as this will not only affect the financial sector, but also any other real sectors.

\section{Acknowledgements}

This work was supported by the Financial Service Authority (OJK), World Bank/International Finance Corporation (IFC), and Institute for Economic and Social Research, Faculty of Economics and Business, Universitas Indonesia (LPEM FEB UI).

\section{References}

1. P. Järvensivu, T. Toivanen, T. Vadén, V. Lähde, A. Majava, J. T. Eronen, Governance of Economic Transition. 1-18 (2018)

2. N. Biswas. Sustainable green banking approach: The need of the hour. Business Spectrum. 1, 1, 32-38 (2011)

3. K. Gobert, M. Poitevin M. Environmental risks: should banks be liable? (CIRANO, 1998)

4. SC. Bihari. Green banking-towards socially responsible banking in India. International Journal of Business Insights \& Transformation. 4, 1 (2010)

5. M.D. Hadad, I. Maftuchah. Sustainable Financing. (Kompas Gramedia, 2015)

6. O. Weber, M. Fenchel, R.W. Scholz. Empirical analysis of the integration of environmental risks into the credit risk management process of European banks. Business Strategy and the Environment. 17, 3, 149-59 (2008)

7. O. Weber, S. Remer. Social banks and the future of sustainable finance. (Routledge, 2011)

8. World Bank Group. Roadmap for a Sustainable Financial System. World Bank (2017)

9. Cambridge Centre for Sustainable Finance. Environmental risk analysis by financial institutions: a review of global practice. (Cambridge Institute for Sustainability Leadership, 2016) 